bioRxiv preprint doi: https://doi. org/10.1101/2021.04.16.440165; this version posted April 18, 2021. The copyright holder for this preprint (which was not certified by peer review) is the author/funder, who has granted bioRxiv a license to display the preprint in perpetuity. It is made available under aCC-BY-NC-ND 4.0 International license.

\title{
Behavioural stress feedback loops in benthic invertebrates caused by pH drop-induced metabolites
}

Lauric Feugere ${ }^{1}$, Lauren Angell ${ }^{1}$, James Fagents ${ }^{1}$, Rebecca Nightingale ${ }^{1}$, Kirsty Rowland ${ }^{1}$, Saffiyah Skinner ${ }^{1}$, Jorg Hardege ${ }^{1}$, Helga Bartels-Hardege ${ }^{1}$, Katharina C. Wollenberg Valero ${ }^{1 *}$

${ }^{1}$ Department of Biological and Marine Sciences, University of Hull, Cottingham Road, Kingston-upon-Hull HU67RX, United Kingdom.

8 *Corresponding author: k.wollenberg-valero@ hull.ac.uk, ORCID: 0000-0001-8858-1804 
bioRxiv preprint doi: https://doi.org/10.1101/2021.04.16.440165; this version posted April 18,2021 . The copyright holder for this preprint (which was not certified by peer review) is the author/funder, who has granted bioRxiv a license to display the preprint in perpetuity. It is made available under aCC-BY-NC-ND 4.0 International license.

\section{Abstract}

10 Studies on $\mathrm{pH}$ stress in marine animals typically focus on direct or species-specific aspects. We here test the 11 hypothesis that a drop to $\mathrm{pH}=7.6$ indirectly affects the intra- and interspecific interactions of benthic 12 invertebrates by means of chemical communication. We recorded fitness-relevant behaviours of small hermit crabs Diogenes pugilator, green shore crabs Carcinus maenas, and harbour ragworms Hediste diversicolor in response to short-term $\mathrm{pH}$ drop, and to putative stress metabolites released by conspecifics or gilt-head sea bream Sparus aurata during 30 minutes of acute $\mathrm{pH}$ drop. Not only did acute $\mathrm{pH}$ drop itself impair time to find 16 a food cue in small hermit crabs and burrowing in harbour ragworms, but similar effects were observed under exposure to $\mathrm{pH}$ drop-induced stress metabolites. Stress metabolites from $S$. aurata, but not its regular control metabolites, also induced avoidance responses in all recipient species. Here, we confirm that a short-term abrupt $\mathrm{pH}$ drop, an abiotic stressor, has the capacity to trigger the release of metabolites which induce behavioural responses in conspecific and heterospecific individuals, which can be interpreted as a behavioural cost. Our findings that stress responses can be indirectly propagated through means of chemical communication warrant further research to confirm the effect size of the behavioural impairments caused by stress metabolites and to characterise their chemical nature.

Keywords: behavioural cost, stress propagation, stress metabolites, chemical communication, ocean acidification 
bioRxiv preprint doi: https://doi.org/10.1101/2021.04.16.440165; this version posted April 18, 2021. The copyright holder for this preprint (which was not certified by peer review) is the author/funder, who has granted bioRxiv a license to display the preprint in perpetuity. It is made available under aCC-BY-NC-ND 4.0 International license.

\section{Introduction}

Compared to the open ocean, coastal areas and particularly intertidal zones are highly variable environments characterised by abrupt changes in water parameters. This includes fluctuations in $\mathrm{pH}$ beyond 0.3 units, the levels predicted for average change related to the process of ocean acidification towards the end of the century (Caldeira and Wickett, 2003; Sabine et al., 2004; IPCC, 2019). While this may mean that intertidal species are more resilient to climate change due to their acquired tolerances of $\mathrm{pH}$ fluctuations, it also forces them to live more frequently near their physiological tolerance limits (Truchot and Duhamel-Jouve, 1980; Hofmann et al., 2011; Sokolova, 2018; Wolfe et al., 2020). Superimposing ocean acidification on natural pH fluctuations may further increase the variability of organisms' responses (Eriander et al., 2015). Therefore, organisms inhabiting intertidal areas are interesting models to study the effects of short-term $\mathrm{pH}$ fluctuations within the IPCC predicted range. A low environmental $\mathrm{pH}$ can alter animal behaviour through several direct or indirect pathways, which include (i) deviation of energy budgets towards the stress response (Pörtner, 2008), (ii) fleeing to avoid the sources of stress (Pörtner and Peck, 2010; Abreu et al., 2016), (iii) disrupted information detection and processing leading to impaired decision-making (Briffa et al., 2012), and (iv) alteration of the chemical signals themselves impacting the sensory environment and the transfer of information (Wyatt et al., 2014; Roggatz et al., 2016, 2019). Behavioural effects triggered by lowered $\mathrm{pH}$ are known to occur in different taxonomic groups such as crustaceans (de la Haye et al., 2011), marine ragworms (Bond, 2018), and fish (Munday et al., 2009), although recent research debate on both their ubiquitousness and their effect size (Clark et al., 2020a; Clements et al., 2020b, but see Clark et al., 2020b; Munday et al., 2020).

In aquatic environments, where visibility can be limited, infochemicals and chemosensory functions, such as pheromones used for mating (Karlson and Lüscher, 1959) are crucial for communication (Hardege, 1999; Jordão and Volpato, 2000; Hay, 2009; Ashur et al., 2017). However, they are also a mechanism to propagate stress - but to date mostly researched within the context of biotic stressors. For example, alarm cues released following mechanical damage from fish epidermal club cells can trigger panic reactions in conspecifics and heterospecifics (Toa et al., 2004; Júnior et al., 2010). Such mechanisms of chemical communication also occur in invertebrates, as evidenced by the reduced out-of-burrow activity of the marine polychaete Alitta virens exposed to damaged conspecifics (Watson et al., 2005; Ende et al., 2017). Disturbance cues refer to chemicals that may be stored in gill epithelium or urine, and are released voluntarily or involuntarily by disturbed or stressed prey, to induce early antipredator responses in recipients to anticipate potential threats (Bairos-Novak et al., 2017; Goldman et al., 2020a). The central role of chemical communication in the aquatic environment and the recent evidence of its impairment by ocean acidification pinpoints the need for a deeper understanding of such potential environmental modulation of chemical signalling (Chivers et al., 2013). Overall, though, it is not well understood yet whether abiotic stressors such as $\mathrm{pH}$ drop can also induce the release of chemical cues and whether these can propagate the stress response to other individuals. For such 61 cues, we here introduce the term 'stress metabolites' as defining such compounds released, voluntarily or not, 62 by an organism in response to abiotic stressors. These can be detected and processed by conspecifics and/or 
bioRxiv preprint doi: https://doi org/101101/2021.04 16.440165; this version posted April 18, 2021. The copyright holder for this preprint (which was not certified by peer review) is the author/funder, who has granted bioRxiv a license to display the preprint in perpetuity. It is made available under aCC-BY-NC-ND 4.0 International license.

of indirect stress propagation might constitute positive feedback loops, defined as the propagation of stress responses within or between species by means of stress metabolites. Detecting stress metabolites may allow other individuals to modify their behaviour to avoid a change in the abiotic environment, and communities to coordinate or potentiate their response to ensure survival (Mothersill et al., 2007; Giacomini et al., 2015; Abreu et al., 2016). However, to investigate the function of any $\mathrm{pH}$ drop-induced chemical cues, the original stressor ( $\mathrm{pH}$ drop) must first be removed from the experimental design.

In this study, we investigate the indirect effects of $\mathrm{pH}$ drop through stress metabolites induced by it on fitnessrelevant behaviours within and among species inhabiting the intertidal zone. Using a full factorial design, we test the hypothesis that an acute $\mathrm{pH}$ drop to end-of-century level (7.6) will both directly and indirectly affect behaviour through the induction of stress metabolites. We observed three marine invertebrates (small hermit crab Diogenes pugilator, green shore crab Carcinus maenas, and harbour ragworm Hediste diversicolor) exposed to control $\mathrm{pH}$ and $\mathrm{pH}$ drop in combination with conditioned water from both conspecifics and their potential vertebrate predator, the gilt-head sea bream $S$. aurata.

\section{Methods}

\section{Experimental design}

Small hermit crabs Diogenes pugilator and green shore crabs Carcinus maenas were collected in autumn at low tide in the Ria Formosa lagoon (Portugal). Harbour ragworms (Hediste diversicolor) were sourced via a local supplier (Valbaits) from the Setubal lagoon (Portugal). Animals were acclimated for one week at $\mathrm{pH} 8.2$ in large communal tanks mimicking natural habitats at the Ramalhete Marine Station (CCMAR, Faro, Portugal) in a direct $\mathrm{CO}_{2}$-controlled system with $p \mathrm{CO}_{2}$ constantly measured and adjusted as described in Sordo et al. (2016). Seawater parameters were measured daily (mean temperature: $18.90^{\circ} \mathrm{C} \pm 0.97^{\circ} \mathrm{C}$, mean salinity: $35.58 \pm 0.19$, mean dissolved oxygen: $91.60 \% \pm 2.15 \%$ ). A total pool of approx. 100-120 D. pugilator, 150 $200 \mathrm{C}$. maenas, and over $150 \mathrm{H}$. diversicolor was used during the experimental period, yielding a total of 921 observations. Because no individual marking could be achieved, we aimed to space out the reuse of animals in successive behavioural assays by circulating animals through recovery tanks afterwards, before returning them to their stock population tanks once a day. Animal reuse was randomized across treatments and treatments randomized per day to prevent any confounding effects on the measured behaviours. All experiments were conducted in October 2019, except one independent set of observations $(n=40)$ in $C$. maenas conducted in September 2018, which was analysed together with the 2019 data with the year treated as a covariate.

A three-way factorial design of $\mathrm{pH}$ drop $\mathrm{x}$ stress metabolites $\mathrm{x}$ donor species was generated to study the effects of acute $\mathrm{pH}$ drop, stress metabolites induced by it, and their combination versus a control containing regular metabolites (control metabolites) (Figure 1). Metabolite donor species were D. pugilator, C. maenas, $H$. diversicolor (called conspecific donors) and the potential predator Sparus aurata (called heterospecific donor). Metabolite donors were conditioned for 30 minutes in seawater at regular $\mathrm{pH}\left(\mathrm{pH} 8.2,400 \mu\right.$ atm $\mathrm{CO}_{2}$, putatively inducing control metabolite release), or $\mathrm{pH}$ drop $\left(\mathrm{pH} 7.6,700 \mu \mathrm{atm} \mathrm{CO}_{2}\right.$, putatively inducing stress metabolite release). Recipient species were $D$. pugilator, $C$. maenas, and $H$. diversicolor which received water 
bioRxiv preprint doi: https://doi.org/10.1101/2021.04.16 440165; this version posted April 18, 2021. The copyright holder for this preprint (which was not certified by peer review) is the author/funder, who has granted bioRxiv a license to display the preprint in perpetuity. It is made available under aCC-BY-NC-ND 4.0 International license.

containing either conspecific or heterospecific metabolites). To achieve the full factorial design, recipient species received either control or stress metabolites and were tested in either control $\mathrm{pH}$ (8.2) or $\mathrm{pH}$ drop $(\mathrm{pH}$ = 7.6), by re-adjusting the $\mathrm{pH}$ of the conditioned water before each bioassay. Overall, four different experimental treatments were obtained: (i) putative control metabolites at $\mathrm{pH} 8.2(\mathrm{CM})$, (ii) putative control metabolites at $\mathrm{pH} 7.6$ (pH drop), (iii) putative stress metabolites at $\mathrm{pH} 8.2$ (SM), (iv) and putative stress metabolites at $\mathrm{pH} 7.6(\mathrm{pH}$ drop+SM). Testing conspecific and heterospecific metabolites with three recipient species amounted to a total of twelve treatments. Prior to use in recipient species, conditioned seawater from $H$. diversicolor and $S$. aurata $(0.0067 \mathrm{fish} / \mathrm{L})$ was tenfold diluted in fresh system seawater at the desired $\mathrm{pH}$. To explore the possibility that stress metabolites are equivalent to highly concentrated control metabolites, we additionally tested the effects of undiluted $S$. aurata control metabolites at $\mathrm{pH} 8.2$ in $H$. diversicolor and $D$. pugilator. See supplementary information for further details on treatments (Table S1) and water conditioning (supplementary methods).

\section{Behavioural bioassays and respirometry}

For each of the four conditions, we measured the time to find a feeding cue (1/10 diluted mussel juice) vs. a mock (seawater) cue in D. pugilator and C. maenas, or to bury the head entirely in the sand in H. diversicolor, and dubbed this variable 'time-to-success'. Behavioural assays were terminated once the animal successfully grabbed the ballasted sponge containing the feeding cue with their pincers (D. pugilator and C. maenas) or buried its entire head ( $H$. diversicolor), or at a maximum time of 300 seconds. Both feeding and burrowing behaviours are tested response variables in crabs (de la Haye et al., 2012; Wang et al., 2018) and ragworm (Bhuiyan et al., 2021) exposed to pH drop. Additionally, avoidance behaviour was binary coded. In $D$. pugilator and C. maenas, these avoidance behaviours included freezing (suddenly retreating into the shell or attempting to burrow, sudden and lasting arrest in locomotion), and escaping (walking along the walls or retreating into a corner of the tank). Such freeze and escape behaviours indicate danger in crustaceans (Katz and Rittschof, 1993; Perrot-Minnot et al., 2017; Tomsic et al., 2017). In H. diversicolor, avoidance behaviours consisted of freezing, which might be accompanied by spread of jaws, sideways-undulating behaviour, and formation of a noticeable slime cap whilst outside the sediment. These behaviours indicate extreme stress in marine polychaetes (Mouneyrac et al., 2003; Burlinson and Lawrence, 2007; McBriarty et al., 2018). The feeding cues were randomly assigned left or right to the crabs. Additionally, respiration rates of $C$. maenas were monitored immediately after their use in feeding behaviour assays in a two-way factorial design of $\mathrm{pH}$ drop x stress metabolites using only conspecific donor metabolites. See supplementary methods for further details on behavioural assays and respirometry.

\section{Statistical analysis}

Avoidance behaviours were analysed using generalised linear models for logit regression with binomial distribution using the stats $\mathrm{R}$ package ( $\mathrm{R}$ Core Team, 2020). Time-to-success was modelled for the time to reach a feeding cue in D. pugilator and C. maenas or to burrow the head in H. diversicolor depending on the 
bioRxiv preprint doi: https://doi org/10.1101/2021.04 16.440165; this version posted April 18, 2021. The copyright holder for this preprint (which was not certified by peer review) is the author/funder, who has granted bioRxiv a license to display the preprint in perpetuity. It is made available under aCC-BY-NC-ND 4.0 International license.

three predictors: $\mathrm{pH}$ drop, stress metabolites, and donor. Time-to-success data was analysed with a time-toevent analysis (also called survival analysis) using Cox proportional hazard models from the survival $\mathrm{R}$ package (Therneau and Grambsch, 2000; Therneau, 2021). The event being the success of food cue location (in crabs) or burrowing the head in sediment (in worms), the analysis was hereafter referred to as 'time-tosuccess analysis'. The exponentiated estimates (hazard ratios) from the Cox proportional hazard models were expressed as 'success ratio'. Success ratios were visualised using the plot_model function from the sjPlot $\mathrm{R}$ package (Lüdecke, 2021). The 'success probability' (the probability of the feeding or burrowing event occurring at any time over 300s) over time was represented by Kaplan-Meier curves drawn using the survminer R package (Kassambara et al., 2020). Animals not reaching the feeding cue or not burying their head were censored and assigned the maximum time of ' $300+$ '. The oxygen measurements were transformed using the additive-inverse slope coefficients standardised to the carapace width and rescaled to the mean additive-inverse slope coefficient of the control CM as shown in equation (1) to yield respiration rates.

respiration rate $=(-a /$ size $) /($ mean - a of control $)$

where $\mathrm{a}$ is the slope of the oxygen levels $(\%)$ as a function of time (s) and the size is proxied by the carapace width.

All statistical models always included the main effects and interaction terms of the binary predictors $\mathrm{pH}$ drop ( $\mathrm{pH}=8.2$ vs. $\mathrm{pH}=7.6$ ), stress metabolites (stress metabolites vs. control metabolites), and donor (conspecific vs. heterospecific). Covariates (year, number of water uses, crab size, where relevant) were included in models when deemed significant compared to the null model by an ANOVA Chi-square test from the stats R package (R Core Team, 2020). Overall model fit p-values were retrieved from the ANOVA Chi-squared test or the Likelihood ratio test for generalised linear models and Cox-proportional models, respectively. Pairwise comparisons between treatments involved in the interaction term between the three predictors were obtained from statistical models using the emmeans $\mathrm{R}$ package (Lenth, 2021), wherein false discovery rate p-value adjustments were applied for post-hoc term-wide multiple testing.

To investigate the possibility that stress metabolites are equivalent to highly concentrated control metabolites (which were present in $\mathrm{CM}$ and $\mathrm{pH}$ drop treatments but in tenfold dilution), additional tests compared the behavioural response of $D$. pugilator and $H$. diversicolor to tenfold diluted stress metabolites and control metabolites to that of undiluted control metabolites from S. aurata.

Effect sizes of the respiration rates were measured as Cohen's d using the effsize R package (Torchiano, 2020) for estimates between two groups, or according to Lenhard and Lenhard (2016) for estimates of the interaction term between $\mathrm{pH}$ drop and stress metabolites predictors. Effect sizes were classified following the classification given in Sawilowsky (2009). All statistical analyses were conducted in RStudio (RStudio Team, 2020) with a significance threshold of $P \leq 0.05$. See $R$ script, datasets, and supplementary information for further details. 
bioRxiv preprint doi: https://doi.org/10.1101/2021.04.16 440165; this version posted April 18, 2021. The copyright holder for this preprint (which was not certified by peer review) is the author/funder, who has granted bioRxiv a license to display the preprint in perpetuity. It is made available under aCC-BY-NC-ND 4.0 International license.

\section{Results}

\section{Response of small hermit crab Diogenes pugilator to $\mathrm{pH}$, stress metabolite, and donor predictors}

The time-to-success analysis was not conclusive for the stress metabolite predictor in D. pugilator (Figure 2A, Table $1, \mathrm{Z}=-0.66, \mathrm{P}=0.5073$ ). On the other hand, the Cox proportional hazard model (overall Likelihood ratio test model fit: $\mathrm{P}=0.06$ ) found that both $\mathrm{pH}$ drop (feeding success ratio $=0.47, \mathrm{Z}=-2.14, \mathrm{P}=0.0325$ ) and metabolites from $S$. aurata (feeding success ratio $=0.35, \mathrm{Z}=-2.76, \mathrm{P}=0.0058$ ) had significant negative effects on the feeding success ratio of $D$. pugilator. In addition, there was a significant interaction between $\mathrm{pH}$ drop and metabolite donor terms on the feeding success of $D$. pugilator $(\mathrm{Z}=2.19, \mathrm{P}=0.0289)$. Overall, $\mathrm{pH}$ drop induced a significantly lower success (risk) score in the conspecific treatment (Figure 2B). Post-hoc analyses evidenced that all treatments ( $\mathrm{CM}, \mathrm{pH}$ drop, $\mathrm{SM}$, and $\mathrm{pH}$ drop+SM) induced similar feeding time responses in both the conspecific and heterospecific donor groups (Table S2).

Avoidance responses of $D$. pugilator did not depend on $\mathrm{pH}$ drop $(\mathrm{Z}=0.25, \mathrm{P}=0.8049)$ nor stress metabolites $(\mathrm{Z}=-0.25, \mathrm{P}=0.7995$, overall Chi-square test model fit: $\mathrm{P}<0.0001$, Table 2$)$, but were significantly more pronounced when metabolites originated from $S$. aurata $(69 \%)$ instead of conspecifics $(26 \%, \mathrm{Z}=2.46, \mathrm{P}=$ 0.0139 , Figure 3, Table 2). After splitting the display of avoidance behaviour by donor, pairwise comparisons failed to find differences between the four treatments ( $\mathrm{CM}$, $\mathrm{pH}$ drop, $\mathrm{SM}$, and $\mathrm{pH}$ drop+SM), but confirmed that the donor effect existed across all four treatments (Table S3, Figure 3). However, partitioning the avoidance behaviour of $D$. pugilator into freezing and escaping responses evidenced that escaping significantly increased with S. aurata control metabolites only when tested in pH drop (Figures S1-S2, Tables S4-S7, see supplementary results).

\section{Response of green shore crab Carcinus maenas to $\mathrm{pH}$, stress metabolite, and donor predictors}

The Cox proportional hazard model (overall Likelihood ratio test model fit: $\mathrm{P}=0.009$ ) showed that the feeding success ratio of $C$. maenas did not significantly vary with $\mathrm{pH}(\mathrm{Z}=-0.80 \mathrm{P}=0.4247)$, metabolites $(\mathrm{Z}=0.68, \mathrm{P}$ $=0.4989)$, nor donor $(\mathrm{Z}=1.09, \mathrm{P}=0.2773)$ terms (Figure 2, Table 1). Nevertheless, all interaction terms were significant. Post-hoc tests revealed that time-to-success responses were similar across treatments $\mathrm{CM}, \mathrm{pH}$ drop, $\mathrm{SM}$, and $\mathrm{pH}$ drop+SM when C. maenas received conspecific metabolites (Table S8). This pattern changed when $S$. aurata was the metabolite donor as evidenced by significantly lower feeding success scores in $C$. maenas exposed to $\mathrm{pH}$ drop $(\mathrm{Z}=2.97, \mathrm{P}=0.0179), \mathrm{SM}(\mathrm{Z}=2.48, \mathrm{P}=0.0394)$, and the trend for $\mathrm{pH}$ drop+SM $(\mathrm{Z}=2.20, \mathrm{P}=0.0563)$, compared to the control $\mathrm{CM}$.

In C. maenas, the predictors $\mathrm{pH}$ drop $(\mathrm{Z}=-1.23, \mathrm{P}=0.2195)$, stress metabolites $(\mathrm{Z}=-1.23, \mathrm{P}=0.2195)$, and donor $(\mathrm{Z}=-1.23, \mathrm{P}=0.5785)$ did not alter avoidance responses but their interaction terms were significant (overall Chi-square test model fit: $\mathrm{P}<0.0001$, Table 2, Figure 3). Pairwise comparisons showed no differences between the four treatments ( $\mathrm{CM}, \mathrm{pH}$ drop, $\mathrm{SM}, \mathrm{pH}$ drop+SM) in avoidance patterns of $C$. maenas receiving conspecific metabolites. Conversely, $C$. maenas facing $S$. aurata metabolites while experiencing treatments of $\mathrm{pH}$ drop $(94 \%, \mathrm{Z}=-3.60, \mathrm{P}=0.0020), \mathrm{SM}(75 \%, \mathrm{Z}=-3.28, \mathrm{P}=0.0031)$, and $\mathrm{pH}$ drop+SM $(56 \%, \mathrm{Z}=-2.33$, $\mathrm{P}=0.04)$ significantly increased their avoidance display compared to control CM (18\%). Moreover, $\mathrm{pH}$ drop 
bioRxiv preprint doi: https://doi org/10.1101/2021.04.16 440165; this version posted April 18, 2021. The copyright holder for this preprint (which was not certified by peer review) is the author/funder, who has granted bioRxiv a license to display the preprint in perpetuity. It is made available under aCC-BY-NC-ND 4.0 International license.

combined with stress metabolites ( $\mathrm{pH}$ drop+SM treatment) instead of control metabolites ( $\mathrm{pH}$ drop treatment) significantly lowered avoidance behaviours $(Z=2.21 \mathrm{P}=0.0405$, Table S9, Figure 3). Partitioning the avoidance behaviour of $C$. maenas into freezing and escaping responses evidenced that escaping explained the avoidance response whereas no clear patterns were observed in the freezing behaviour (Figures S1-S2, Tables S10-S13, see supplementary results). Lastly, neither $\mathrm{pH}$ drop nor stress metabolites altered the respiration rates of $C$. maenas although the interaction was near to significant $(\mathrm{P}=0.0531$, Figure $\mathrm{S} 3$, Table S14).

\section{Response of harbour ragworm Hediste diversicolor to $\mathrm{pH}$, stress metabolite, and donor predictors}

Burrowing success responses of $H$. diversicolor did not depend on the donor species $(\mathrm{P}=0.1093$, Figure 2 , Table 1). However, the Cox proportional hazard model (overall Likelihood ratio test model fit: $\mathrm{P}<0.0001$ ) evidenced that both $\mathrm{pH}$ drop (burrowing success ratio $=0.30, \mathrm{Z}=-3.91, \mathrm{P}<0.0001$ ) and stress metabolites (burrowing success ratio $=0.35, \mathrm{Z}=-3.42, \mathrm{P}=0.0006$ ) terms significantly altered burrowing time responses of $H$. diversicolor. Significant interactions between the main predictors required to decipher the involvement of within-donor treatment effects (Table S15). Post-hoc tests revealed that $\mathrm{pH}$ drop $(\mathrm{Z}=3.91, \mathrm{P}=0.0006)$, SM $(\mathrm{Z}=3.43, \mathrm{P}=0.0012)$, and $\mathrm{pH}$ drop+SM $(\mathrm{Z}=3.47, \mathrm{P}=0.0012)$ treatments significantly lowered burrowing success scores compared to the control CM in $H$. diversicolor exposed to conspecific metabolites. Moreover, $H$. diversicolor facing $S$. aurata metabolites had lower burrowing success scores in the $\mathrm{pH}$ drop+SM treatment compared to the control $\mathrm{CM}(\mathrm{Z}=3.35, \mathrm{P}=0.0049)$.

$H$. diversicolor displayed more avoidance in response to $S$. aurata metabolites (47\%) compared to conspecific metabolites $(20 \%, \mathrm{Z}=1.09, \mathrm{P}=0.0006$, overall Chi-square test model fit: $\mathrm{P}<0.0001$, Table 2, Figures 3$) . H$. diversicolor exposed to $S$. aurata metabolites were not affected by $\mathrm{pH}$ drop $(\mathrm{Z}=-0.01, \mathrm{P}=0.9906)$ whereas stress metabolites induced significantly more avoidance than control metabolites $(Z=-5.30, P<0.0001$, overall Chi-square test model fit: $\mathrm{P}<0.0001$, Table 2). There were no differences across $\mathrm{pH}$ drop, SM, and $\mathrm{pH}$ drop+SM treatments in $H$. diversicolor receiving conspecific metabolites (Table S16). Pairwise comparisons revealed that the SM treatment $(93 \%)$ triggered significantly more avoidance than $\mathrm{CM}(33 \%, \mathrm{Z}=-4.31, \mathrm{P}=$ $0.0001)$ and $\mathrm{pH}$ drop+SM treatments $(51 \%, \mathrm{Z}=3.92, \mathrm{P}=0.0003)$. Specimens of $H$. diversicolor exposed to $S$. aurata metabolites displayed different avoidance responses in the control treatment CM (video 1) compared to $\mathrm{pH}$ drop (slowed-down burrowing response, video 2), SM (sideways-undulating behaviour with body flips, video 3), and $\mathrm{pH}$ drop+SM (raised head and spread mouth parts with freezing behaviour in video 4 and sloweddown movement with sideways undulating behaviour in video 5).

\section{Discussion}

\section{Direct effects of $\mathrm{pH}$ drop and donor type on assay success and avoidance behaviours}

Changes in fitness-relevant behaviours to acute $\mathrm{pH}$ change can be expected to show high variance and small effect sizes (Clark et al., 2020a), and may therefore require large observational datasets. In this study, we performed over 900 behavioural observations, and our results reflect this high variance. Sparus aurataconditioned water, whether it contained control metabolites or $\mathrm{pH}$ stress-induced metabolites, elicited 
bioRxiv preprint doi: https://doi org/10.1101/2021.04 16.440165; this version posted April 18, 2021. The copyright holder for this preprint (which was not certified by peer review) is the author/funder, who has granted bioRxiv a license to display the preprint in perpetuity. It is made available under aCC-BY-NC-ND 4.0 International license.

avoidance in all recipient species which can be attributed to antipredator behaviours. Despite the donor effect however, much of the behavioural variance was explained by the effects of $\mathrm{pH}$ drop and stress metabolites, their interaction, or their interaction with the donor term (Figure 2).

We found that $\mathrm{pH}$ drop lowered success ratios in feeding and burrowing in Diogenes pugilator and Hediste diversicolor, respectively. Such low pH-induced impairments of fitness-relevant behaviours were previously found in hermit crabs Pagurus bernhardus and P. tanneri and may indicate impaired decision-making (de la Haye et al., 2011, 2012; Kim et al., 2015). Past literature also reported delayed burrowing responses in the harbour ragworm $H$. diversicolor exposed for 28 days to $\mathrm{pH}$ drop (Bhuiyan et al., 2021), and an inverse relationship between burrowing and $\mathrm{pH}$ in the king ragworm Alitta virens (Batten and Bamber, 1996). These behavioural alterations may reflect the cost of acid-base regulation to counteract hypercapnia (Pörtner, 2008), as marine ragworms overexpress the acid-base regulator Carbonic Anhydrase (CA) at the expense of energy reserves in response to acidification (Freitas et al., 2016; Wage et al., 2016). In the longer term, behavioural costs of an altered burrowing activity may extend to crucial ecological functions as shown by the diminished bioturbation activity of $H$. diversicolor in similar conditions (Bond, 2018). In contrast, Carcinus maenas did not delay its feeding response to $\mathrm{pH}$ drop in presence of conspecific metabolites, which supports recent observations of ocean acidification having weaker effects than previously expected on marine animal behaviour (Clark et al., 2020a; Clements et al., 2020a, 2020b, 2021) including feeding responses in aquatic arthropods (Clements and Darrow, 2018). The resilience to $\mathrm{pH}$ stress in C. maenas may be due to their extracellular $\mathrm{pH}$ regulatory capacities allowing them to maintain feeding during short-term assays (Appelhans et al., 2012). Therefore, short-term hypercapnia is not a strong stressor in C. maenas, due to its $\mathrm{pH}$-variable intertidal habitat (Fehsenfeld et al., 2011), which is supported by its ability to maintain respiration rates in our study. Other than reduced success ratios, $\mathrm{pH}$ drop itself did not induce any avoidance behaviours indicative of stress.

Besides the direct effect of $\mathrm{pH}$ drop on behaviour, previous studies on ocean acidification also found contrasting effects of pH drop on predator-prey interactions (Draper and Weissburg, 2019). Here, we observed an increased escaping tendency of $C$. maenas in response to $S$. aurata control metabolites in $\mathrm{pH}$ drop but not in control $\mathrm{pH}$. Although this was not the main focus of our study, it could mean that $\mathrm{pH}$ drop renders predator odour more potent for its prey, for example through $\mathrm{pH}$-dependent changes in odour molecular structure, receptor binding, or information processing (Munday et al., 2009; Roggatz et al., 2016, 2019; Schirrmacher et al., 2020).

\section{Indirect effects of pH drop on recipients' behaviour through stress chemical communication}

Despite the above-mentioned species-specific direct effects of $\mathrm{pH}$ drop on behaviour success ratios, we could show here that $\mathrm{pH}$ drop also has indirect effects on behaviour by altering chemical communication. We found that stress metabolites released by animals exposed to $\mathrm{pH}$ drop altered feeding and burrowing, and increased avoidance behaviours, but that the response was donor and recipient species-specific. Hermit crabs $D$. pugilator did not react to any stress metabolites. Significant responses in the other two recipient species, 
bioRxiv preprint doi: https://doi.org/10.1101/2021.04 16.440165; this version posted April 18, 2021. The copyright holder for this preprint (which was not certified by peer review) is the author/funder, who has granted bioRxiv a license to display the preprint in perpetuity. It is made available under aCC-BY-NC-ND 4.0 International license.

however, were directionally equivalent to those induced by $\mathrm{pH}$ drop itself since it took longer to find a food cue or to burrow the head in the presence of stress metabolites. Although behavioural stress response propagation through chemical communication is well documented for alarm substances and disturbance cues upon predation stress (Giacomini et al., 2015; Abreu et al., 2016; Mathuru, 2016), our results show here that chemical communication induced by abiotic stressors such as $\mathrm{pH}$ drop can trigger the release of waterborne chemicals that in turn trigger a behavioural stress response in its recipients. Stress metabolites conditioned by the potential predator $S$. aurata induced more avoidance behaviours and delayed feeding in $C$. maenas and burrowing in $H$. diversicolor, compared to $S$. aurata control metabolites. Similarly, the presence of conspecific stress metabolites significantly lowered $H$. diversicolor burrowing success ratio compared to conspecific control metabolites.

On the other hand, C. maenas did not react to conspecific stress metabolites. The different behavioural effect of conspecific stress metabolites between crabs and H. diversicolor has several possible explanations ranging from different defence strategies related to stress risk perception and evaluation (Hazlett, 1985; Bairos-Novak et al., 2017, 2018; Goldman et al., 2020b) to different types, concentrations, or ratios of the released chemicals (Júnior et al., 2010; Morishita and Barreto, 2011). As we have shown here a pH drop to 7.6 is not a strong stressor in crabs (Fehsenfeld et al., 2011) which may explain that we failed to observe responses to water from $\mathrm{pH}$ drop-conditioned conspecific green shore crabs. However, the presence of stress metabolites conditioned by $S$. aurata caused a marked drop in the success ratio of $C$. maenas at low (but not control) $\mathrm{pH}$, evidenced by significant interaction terms.

Whilst we did not investigate their chemical structure, our experiment allows us to characterize novel properties of stress metabolites. Stress metabolites, like disturbance cues, potentially consist of regularly excreted metabolites such as urea and ammonia (Bairos-Novak et al., 2017; Shrivastava et al., 2019). The fact that behavioural responses of $H$. diversicolor and $D$. pugilator remained unchanged even when we used undiluted control metabolites (Tables S17-S18), might mean that stress metabolites are not just upconcentrated control metabolites. We also observed that avoidance behaviours by both $C$. maenas and $H$. diversicolor became less pronounced with subsequent water uses, showing that the cues are either volatile or have a very short half-life (less than half a day) in seawater. Alternatively, recipients may be able to discriminate degraded versus fresh metabolites and react accordingly to the degree of threat they may indicate (Fuselier et al., 2009; Bairos-Novak et al., 2018). This shows that stress metabolites induced by pH drop are either not identical with metabolites released in normal $\mathrm{pH}$, and/or are at least more than tenfold higher concentrated than control metabolites.

The avoidance behaviours we recorded in this study are known indicators of stress. S. aurata stress metabolites elicited atypical freezing, eversion of the proboscis, mucus secretion, flipping and sideways-undulating behaviours in $H$. diversicolor which were previously described as indicators for a physiological stress response following exposure to copper sulphate (Burlinson and Lawrence, 2007), antiparasitic drugs (McBriarty et al., 2018), and trace metals (Mouneyrac et al., 2003). We also observed increased freeze and escape responses in 
bioRxiv preprint doi: https://doi.org/10.1101/2021.04 16.440165; this version posted April 18, 2021. The copyright holder for this preprint (which was not certified by peer review) is the author/funder, who has granted bioRxiv a license to display the preprint in perpetuity. It is made available under aCC-BY-NC-ND 4.0 International license.

crabs, which indicate a stress response in crustaceans (Katz and Rittschof, 1993; Perrot-Minnot et al., 2017; Tomsic et al., 2017).

The finding that $S$. aurata $\mathrm{pH}$-induced stress metabolites induced such responses in potential prey species suggests that responses to disturbance cues are not depending on the 'audience', similar as what has been observed in tadpoles (Bairos-Novak et al., 2020). In our study, stress metabolites from $H$. diversicolor altered the burrowing success of conspecifics whereas Watson and colleagues (2005) found that whole-body extracts of $H$. diversicolor did not alter out-of-burrow activities of the king ragworm Alitta virens (of the same subfamily Nereidinae), indicating that stress metabolites may also differ from alarm cues.

A directionally similar response to $\mathrm{pH}$ drop and to the stress metabolites it induces shows that $\mathrm{pH}$ drop can have indirect effects, reminiscent of a positive feedback loop, by which stressed animals negatively influence fitness-relevant behaviours of community members. This was first observed by Hazlett (1985) after freshwater crayfish exposed to water conditioned with heat-stressed conspecifics displayed increased alertness, after returning the conditioned water to normal temperature. Similar indirect effects through chemical signalling from stressed donors to unstressed recipients were also shown in response to different types of biotic stressors such as mock predator chase (Toa et al., 2004; Giacomini et al., 2015), handling (Barcellos et al., 2011), and acute fasting (Abreu et al., 2016), and to physical injury including irradiation (Mothersill et al., 2007) and predation (Frisch, 1938; Mathuru et al., 2012; Oliveira et al., 2013).

\section{Conclusions and Perspectives}

In this study, we could show that short-term $\mathrm{pH}$ drop of a similar magnitude of that experienced within the intertidal zone, but also aligned to end-of-century predicted average values (Chavez et al., 2017; Landschützer et al., 2018), had negative consequences on fitness-relevant behaviours in harbour ragworm $H$. diversicolor and small hermit crab $D$. pugilator. Additionally, we confirm that $\mathrm{pH}$ drop events also impede the same behaviours in the same way indirectly via chemical communication, albeit these effects depended on donor and recipient species. Sea bream $S$. aurata and harbour ragworm $H$. diversicolor stressed by $\mathrm{pH}$ drop released stress metabolites which likely differ from control metabolites and negatively affect fitness-relevant behaviours in metabolite recipients. Stress metabolites induced similar avoidance behaviours as those exhibited under physiological stress, meaning that a stress response was propagated from donor to recipient. These negative indirect effects, or positive feedback loops, warrant further study, especially as our results were inconclusive with regards to the combined treatments of low $\mathrm{pH}$ and stress metabolites. Short-term $\mathrm{pH}$ drops thus involve behavioural additionally to metabolic trade-offs, which is also of interest for better predicting the response of natural and aquaculture systems under ocean acidification combined with tidal $\mathrm{pH}$ fluctuations. We are hopeful that our more than 900 observations and balanced experimental design could overcome most potential limitations, in relation to pseudoreplication due to reusing some animals on different days, and any overestimation of effect sizes related to small sample size (Clements et al., 2020b). Given the potential high ecological significance of indirect negative effects of $\mathrm{pH}$ fluctuations on population fitness, studies aiming to 
bioRxiv preprint doi: $\mathrm{https}$ ://doi.org/10.1101/2021.04.16.440165; this version posted April 18, 2021. The copyright holder for this preprint (which was not certified by peer review) is the author/funder, who has granted bioRxiv a license to display the preprint in perpetuity. It is made available under aCC-BY-NC-ND 4.0 International license.

355 replicate our results should aim to further optimise our experimental design with better technical equipment as 356 that available to us (Baker, 2016). 
bioRxiv preprint doi: https://doi org/10.1101/2021.04 16.440165; this version posted April 18 , 2021. The copyright holder for this preprint (which was not certified by peer review) is the author/funder, who has granted bioRxiv a license to display the preprint in perpetuity. It is made available under aCC-BY-NC-ND 4.0 International license.

\section{$357 \quad$ Funding}

358 This work was supported by the Natural Environment Research Council (NERC) [NE/T001577/1]; and the 359 University of Hull [funding towards the MolStressH2O research cluster].

361 Competing Interests

362 The authors declare no conflicts of interest.

365 All experiments were approved by the University of Hull Ethics Committee under the approvals U020 and 366 FEC_2019_81.

\section{Authors' contributions}

369 KWV designed the study. Experiments were performed by LF, SS, LA, JF, RN, KR, and KWV. LF analysed 370 the data and wrote the first manuscript draft with KWV, JDH and HBH. All authors contributed to the final 371 manuscript.

\section{Acknowledgements}

374 The authors wish to acknowledge J. Pena dos Reis, P. Hubbard, Z. Velez, and all staff members of the 375 CCMAR-Ramalhete Marine Station. JDH and KWV acknowledge funding by Natural Environment Research 376 Council (NERC grant \#NE/T001577/1), and KWV, JDH and LF acknowledge funding by the University of 377 Hull towards the MolStressH2O research cluster. We thank Andrea Murcia for the drawings of Diogenes pugilator, Sparus aurata, and Hediste diversicolor. 
bioRxiv preprint doi: https://doi org/10.1101/2021.04.16.440165; this version posted April 18, 2021. The copyright holder for this preprint (which was not certified by peer review) is the author/funder, who has granted bioRxiv a license to display the preprint in perpetuity. It is made available under aCC-BY-NC-ND 4.0 International license.

\section{References}

Abreu, M. S., Giacomini, A. C. V., Gusso, D., Koakoski, G., Oliveira, T. A., Marqueze, A., et al. (2016). Behavioral responses of zebrafish depend on the type of threatening chemical cues. J. Comp. Physiol. A Neuroethol. Sens. Neural Behav. Physiol. 202, 895-901. doi:10.1007/s00359-016-1129-5.

Appelhans, Y. S., Thomsen, J., Pansch, C., Melzner, F., and Wahl, M. (2012). Sour times: seawater acidification effects on growth, feeding behaviour and acid-base status of Asterias rubens and Carcinus maenas. Mar. Ecol. Prog. Ser. 459, 85-98. doi:10.3354/meps09697.

Ashur, M. M., Johnston, N. K., and Dixson, D. L. (2017). Impacts of Ocean Acidification on Sensory Function in Marine Organisms. Integr. Comp. Biol. 57, 63-80. doi:10.1093/icb/icx010.

Bairos-Novak, K. R., Crane, A. L., Achtymichuk, G. H., Hsin, J., Rivera-Hernández, I. A. E., Simko, O. M., et al. (2020). Forget the audience: tadpoles release similar disturbance cues regardless of kinship or familiarity. Behav. Ecol. Sociobiol. 74(12), 1-10. doi:10.1007/s00265-020-02936-8.

Bairos-Novak, K. R., Crane, A. L., Chivers, D. P., and Ferrari, M. C. O. (2018). Better the devil you know? How familiarity and kinship affect prey responses to disturbance cues. Behav. Ecol. 30, 446-454. doi:10.1093/beheco/ary184.

Bairos-Novak, K. R., Mitchell, M. D., Crane, A. L., Chivers, D. P., and Ferrari, M. C. O. (2017). Trust thy neighbour in times of trouble: background risk alters how tadpoles release and respond to disturbance cues. Proc. Biol. Sci. 284(1863), 20171465. doi:10.1098/rspb.2017.1465.

Baker, M. (2016). 1,500 scientists lift the lid on reproducibility. Nature 533, 452-454. doi:10.1038/533452a.

Barcellos, L. J. G., Volpato, G. L., Barreto, R. E., Coldebella, I., and Ferreira, D. (2011). Chemical communication of handling stress in fish. Physiol. Behav. 103, 372-375. doi:10.1016/j.physbeh.2011.03.009.

Batten, S. D., and Bamber, R. N. (1996). The effects of acidified seawater on the polychaete Nereis virens Sars, 1835. Mar. Pollut. Bull. 32, 283-287. doi:10.1016/0025-326X(95)00163-H.

Bhuiyan, K. A., Rodríguez, B. M., Pires, A., Riba, I., Dellvals, Á., Freitas, R., et al. (2021). Experimental evidence of uncertain future of the keystone ragworm Hediste diversicolor (O.F. Müller, 1776) under climate change conditions. Sci. Total Environ. 750, 142031. doi:10.1016/j.scitotenv.2020.142031.

Bond, D. (2018). Ocean acidification threat? How pH affects burrowing behaviour of Nereis diversicolor and its bearing on mass extinction scenarios. in (EGU General Assembly Conference Abstracts), 6416.

Briffa, M., de la Haye, K., and Munday, P. L. (2012). High $\mathrm{CO}_{2}$ and marine animal behaviour: potential mechanisms and ecological consequences. Mar. Pollut. Bull. 64, 1519-1528. doi:10.1016/j.marpolbul.2012.05.032.

Burlinson, F. C., and Lawrence, A. J. (2007). Development and validation of a behavioural assay to measure the tolerance of Hediste diversicolor to copper. Environ. Pollut. 145, 274-278. doi:10.1016/j.envpol.2005.03.014.

Caldeira, K., and Wickett, M. E. (2003). Oceanography: anthropogenic carbon and ocean pH. Nature 425, 365. doi:10.1038/425365a. 
bioRxiv preprint doi: https://doi org/10.1101/2021.04 16 440165; this version posted April 18, 2021. The copyright holder for this preprint (which was not certified by peer review) is the author/funder, who has granted bioRxiv a license to display the preprint in perpetuity. It is made available under aCC-BY-NC-ND 4.0 International license.

Chavez, F. P., Pennington, J. T., Michisaki, R. P., Blum, M., Chavez, G. M., Friederich, J., et al. (2017). Climate variability and change: response of a coastal ocean ecosystem. Oceanography 30, 128-145. Available at: https://www.jstor.org/stable/26367631.

Chivers, D. P., Dixson, D. L., White, J. R., McCormick, M. I., and Ferrari, M. C. O. (2013). Degradation of chemical alarm cues and assessment of risk throughout the day. Ecol. Evol. 3, 3925-3934. doi:10.1002/ece3.760.

Clark, T. D., Raby, G. D., Roche, D. G., Binning, S. A., Speers-Roesch, B., Jutfelt, F., et al. (2020a). Ocean acidification does not impair the behaviour of coral reef fishes. Nature 577, 370-375. doi:10.1038/s41586-019-1903-y.

Clark, T. D., Raby, G. D., Roche, D. G., Binning, S. A., Speers-Roesch, B., Jutfelt, F., et al. (2020b). Reply to: Methods matter in repeating ocean acidification studies. Nature 586, E25-E27. doi:10.1038/s41586020-2804-9.

Clements, J. C., and Darrow, E. S. (2018). Eating in an acidifying ocean: a quantitative review of elevated $\mathrm{CO} 2$ effects on the feeding rates of calcifying marine invertebrates. Hydrobiologia 820, 1-21. doi:10.1007/s10750-018-3665-1.

Clements, J. C., Poirier, L. A., Pérez, F. F., Comeau, L. A., and Babarro, J. M. F. (2020a). Behavioural responses to predators in Mediterranean mussels (Mytilus galloprovincialis) are unaffected by elevated pCO2. Mar. Environ. Res. 161, 105148. doi:10.1016/j.marenvres.2020.105148.

Clements, J. C., Ramesh, K., Nysveen, J., Dupont, S., and Jutfelt, F. (2021). Animal size and sea water temperature, but not $\mathrm{pH}$, influence a repeatable startle response behaviour in a wide-ranging marine mollusc. Anim. Behav. 173, 191-205. doi:10.1016/j.anbehav.2020.12.008.

Clements, J., Sundin, J., Clark, T. D., and Jutfelt, F. (2020b). An extreme decline effect in ocean acidification ecology. EcoEvoRxiv. doi:10.32942/osf.io/k9dby.

de la Haye, K. L., Spicer, J. I., Widdicombe, S., and Briffa, M. (2011). Reduced sea water pH disrupts resource assessment and decision making in the hermit crab Pagurus bernhardus. Anim. Behav. 82(3), 495-501. doi:10.1016/j.anbehav.2011.05.030.

de la Haye, K. L., Spicer, J. I., Widdicombe, S., and Briffa, M. (2012). Reduced pH sea water disrupts chemo-responsive behaviour in an intertidal crustacean. J. Exp. Mar. Bio. Ecol. 412, 134-140. doi:10.1016/j.jembe.2011.11.013.

Draper, A. M., and Weissburg, M. J. (2019). Impacts of Global Warming and Elevated CO2 on Sensory Behavior in Predator-Prey Interactions: A Review and Synthesis. Front. Ecol. Evol. 7, 307. doi:10.3389/fevo.2019.00072.

Ende, S. S. W., Capelle, J., Kals, J., Schrama, J. W., and Verreth, J. A. J. (2017). A matter of perception: The influence of waterborne signals from fish and conspecifics on the feeding related behavior of Alitta virens (Sars). J. Exp. Mar. Bio. Ecol. 496, 91-96. doi:10.1016/j.jembe.2017.08.004.

Eriander, L., Wrange, A.-L., and Havenhand, J. N. (2015). Simulated diurnal pH fluctuations radically increase variance in — but not the mean of - growth in the barnacle Balanus improvisus. ICES J. Mar. 
bioRxiv preprint doi: https://doi org/10.1101/2021.04 16 440165; this version posted April 18, 2021. The copyright holder for this preprint (which was not certified by peer review) is the author/funder, who has granted bioRxiv a license to display the preprint in perpetuity. It is made available under aCC-BY-NC-ND 4.0 International license.

Sci. 73, 596-603. doi:10.1093/icesjms/fsv214.

Fehsenfeld, S., Kiko, R., Appelhans, Y., Towle, D. W., Zimmer, M., and Melzner, F. (2011). Effects of elevated seawater $\mathrm{pCO}(2)$ on gene expression patterns in the gills of the green crab, Carcinus maenas. BMC Genomics 12, 488. doi:10.1186/1471-2164-12-488.

Freitas, R., Pires, A., Moreira, A., Wrona, F. J., Figueira, E., and Amadeu M V (2016). Biochemical alterations induced in Hediste diversicolor under seawater acidification conditions. Marine Environmental Research 117, 75-84. doi:10.1016/j.marenvres.2016.04.003.

Frisch, K. (1938). Zur Psychologie des Fisch-Schwarmes. Naturwissenschaften 26, 601-606. doi:10.1007/BF01590598.

Fuselier, L., Rugg, M., Korpi, N., and Wisenden, B. (2009). Lab and field estimates of active time of chemical alarm cues of a cyprinid fish and an amphipod crustacean. Behaviour 146, 1423-1442. doi:10.1163/156853909X440998.

Giacomini, A. C. V. V., de Abreu, M. S., Koakoski, G., Idalêncio, R., Kalichak, F., Oliveira, T. A., et al. (2015). My stress, our stress: blunted cortisol response to stress in isolated housed zebrafish. Physiol. Behav. 139, 182-187. doi:10.1016/j.physbeh.2014.11.035.

Goldman, J. A., Désormeaux, I. S., and Brown, G. E. (2020a). Disturbance cues as a source of risk assessment information under natural conditions. Freshwater Biology 65, 981-986. doi:10.1111/fwb.13484.

Goldman, J. A., Feyten, L. E. A., Ramnarine, I. W., and Brown, G. E. (2020b). Sender and receiver experience alters the response of fish to disturbance cues. Curr. Zool. 66, 255-261. doi:10.1093/cz/zoz050.

Hardege, J. D. (1999). Nereidid polychaetes as model organisms for marine chemical ecology. Hydrobiologia 402, 145-161. doi:10.1023/A:1003740509104.

Hay, M. E. (2009). Marine chemical ecology: chemical signals and cues structure marine populations, communities, and ecosystems. Ann. Rev. Mar. Sci. 1, 193-212. doi:10.1146/annurev.marine.010908.163708.

Hazlett, B. A. (1985). Disturbance pheromones in the crayfishOrconectes virilis. J. Chem. Ecol. 11, 16951711. doi:10.1007/BF01012121.

Hofmann, G. E., Smith, J. E., Johnson, K. S., Send, U., Levin, L. A., Micheli, F., et al. (2011). Highfrequency dynamics of ocean $\mathrm{pH}$ : a multi-ecosystem comparison. PLoS One 6, e28983. doi:10.1371/journal.pone.0028983.

IPCC (2019). IPCC Special Report on the Ocean and Cryosphere in a Changing Climate. , ed. H.-O. Pörtner, D.C. Roberts, V. Masson-Delmotte, P. Zhai, M. Tignor, E. Poloczanska, K. Mintenbeck, A. Alegría, M. Nicolai, A. Okem, J. Petzold, B. Rama, N.M. Weyer (eds.) Intergovernmental Panel on Climate Change.

Jordão, L. C., and Volpato, G. L. (2000). Chemical Transfer of Warning Information in Non-Injured Fish. Behaviour 137, 681-690. doi:10.1163/156853900502286. 
bioRxiv preprint doi: https://doi org/10.1101/2021.04 16 440165; this version posted April 18, 2021. The copyright holder for this preprint (which was not certified by peer review) is the author/funder, who has granted bioRxiv a license to display the preprint in perpetuity. It is made available under aCC-BY-NC-ND 4.0 International license.

Júnior, A. B., Magalhães, E. J., Hoffmann, A., and Ide, L. M. (2010). Conspecific and heterospecific alarm substance induces behavioral responses in piau fish Leporinus piau. Acta Ethol. 13, 119-126. doi:10.1007/s10211-010-0081-6.

Karlson, P., and Lüscher, M. (1959). Pheromone. Naturwissenschaften 46, 63-64. doi:10.1007/BF00599084. Kassambara, A., Kosinski, M., and Biecek, P. (2020). Drawing Survival Curves using "ggplot2” [R package survminer version 0.4.8]. Available at: https://CRAN.R-project.org/package=survminer.

Katz, J. N., and Rittschof, D. (1993). Alarm/investigation responses of hermit crabs as related to shell fit and crab size. Mar. Behav. Physiol. 22, 171-182. doi:10.1080/10236249309378845.

Kim, T. W., Taylor, J., Lovera, C., and Barry, J. P. (2015). CO2-driven decrease in pH disrupts olfactory behaviour and increases individual variation in deep-sea hermit crabs. ICES J. Mar. Sci. 73, 613-619. doi:10.1093/icesjms/fsv019.

Landschützer, P., Gruber, N., Bakker, D. C. E., Stemmler, I., and Six, K. D. (2018). Strengthening seasonal marine $\mathrm{CO} 2$ variations due to increasing atmospheric CO2. Nature Climate Change 8, 146-150. doi:10.1038/s41558-017-0057-x.

Lenhard, W., and Lenhard, A. (2016). Computation of effect sizes. Dettelbach Psychom. Dettelbach, Germany: Psychometrica. doi:10.13140/RG.2.2.17823.92329.

Lenth, R. (2021). emmeans: estimated marginal means, aka least-squares means. R package version 1.5.5-1. Available at: https://cran.r-project.org/web/packages/emmeans.

Lüdecke, D. (2021). Data Visualization for Statistics in Social Science. R package sjPlot version 2.8.7. Available at: https://CRAN.R-project.org/package=sjPlot.

Mathuru, A. S. (2016). Conspecific injury raises an alarm in medaka. Sci. Rep. 6, 36615. doi:10.1038/srep36615.

Mathuru, A. S., Kibat, C., Cheong, W. F., Shui, G., Wenk, M. R., Friedrich, R. W., et al. (2012). Chondroitin fragments are odorants that trigger fear behavior in fish. Curr. Biol. 22, 538-544. doi:10.1016/j.cub.2012.01.061.

McBriarty, G. J., Kidd, K. A., and Burridge, L. E. (2018). Short-Term Effects of the Anti-sea Lice Therapeutant Emamectin Benzoate on Clam Worms (Nereis virens). Arch. Environ. Contam. Toxicol. 74, 539-545. doi:10.1007/s00244-017-0461-2.

Morishita, V. R., and Barreto, R. E. (2011). Black sea urchins evaluate predation risk using chemical signals from a predator and injured con- and heterospecific prey. Mar. Ecol. Prog. Ser. 435, 173-181. doi:10.3354/meps09253.

Mothersill, C., Smith, R. W., Agnihotri, N., and Seymour, C. B. (2007). Characterization of a radiationinduced stress response communicated in vivo between zebrafish. Environ. Sci. Technol. 41, 33823387. doi:10.1021/es062978n.

Mouneyrac, C., Mastain, O., Amiard, J. C., Amiard-Triquet, C., Beaunier, P., Jeantet, A.-Y., et al. (2003). Trace-metal detoxification and tolerance of the estuarine worm Hediste diversicolor chronically exposed in their environment. Mar. Biol. 143, 731-744. 
bioRxiv preprint doi: https://doi org/10.1101/2021.04 16.440165; this version posted April 18, 2021. The copyright holder for this preprint (which was not certified by peer review) is the author/funder, who has granted bioRxiv a license to display the preprint in perpetuity. It is made available under aCC-BY-NC-ND 4.0 International license.

Munday, P. L., Dixson, D. L., Donelson, J. M., Jones, G. P., Pratchett, M. S., Devitsina, G. V., et al. (2009). Ocean acidification impairs olfactory discrimination and homing ability of a marine fish.

Munday, P. L., Dixson, D. L., Welch, M. J., Chivers, D. P., Domenici, P., Grosell, M., et al. (2020). Methods matter in repeating ocean acidification studies. Nature 586, E20-E24. doi:10.1038/s41586-020-2803-X.

Oliveira, T. A., Koakoski, G., Kreutz, L. C., Ferreira, D., da Rosa, J. G. S., de Abreu, M. S., et al. (2013). Alcohol impairs predation risk response and communication in zebrafish. PLoS One 8, e75780. doi:10.1371/journal.pone.0075780.

Perrot-Minnot, M.-J., Banchetry, L., and Cézilly, F. (2017). Anxiety-like behaviour increases safety from fish predation in an amphipod crustacea. $R$ Soc Open Sci 4, 171558. doi:10.1098/rsos.171558.

Pörtner, H. (2008). Ecosystem effects of ocean acidification in times of ocean warming: a physiologist's view. Mar. Ecol. Prog. Ser. 373, 203-217. doi:10.3354/meps07768.

Pörtner, H. O., and Peck, M. A. (2010). Climate change effects on fishes and fisheries: towards a cause-andeffect understanding. J. Fish Biol. 77, 1745-1779. doi:10.1111/j.1095-8649.2010.02783.x.

R Core Team (2020). R: A Language and Environment for Statistical Computing. Available at: https://www.R-project.org/.

Roggatz, C. C., Fletcher, N., Benoit, D. M., Algar, A. C., Doroff, A., Wright, B., et al. (2019). Saxitoxin and tetrodotoxin bioavailability increases in future oceans. Nat. Clim. Chang. 9, 840-844. doi:10.1038/s41558-019-0589-3.

Roggatz, C. C., Lorch, M., Hardege, J. D., and Benoit, D. M. (2016). Ocean acidification affects marine chemical communication by changing structure and function of peptide signalling molecules. Glob. Chang. Biol. 22, 3914-3926. doi:10.1111/gcb.13354.

RStudio Team (2020). RStudio: Integrated Development Environment for R. Available at: http://www.rstudio.com/.

Sabine, C. L., Feely, R. A., Gruber, N., Key, R. M., Lee, K., Bullister, J. L., et al. (2004). The oceanic sink for anthropogenic CO2. Science 305, 367-371. doi:10.1126/science.1097403.

Sawilowsky, S. S. (2009). New Effect Size Rules of Thumb. J. Mod. Appl. Stat. Methods 8, 26. doi:10.22237/jmasm/1257035100.

Schirrmacher, P., Roggatz, C. C., Benoit, D. M., and Hardege, J. D. (2020). Ocean Acidification Amplifies the Olfactory Response to 2-Phenylethylamine: Altered Cue Reception as a Mechanistic Pathway? bioRxiv, 2020.10.08.329870. doi:10.1101/2020.10.08.329870.

Shrivastava, J., Ndugwa, M., Caneos, W., and De Boeck, G. (2019). Physiological trade-offs, acid-base balance and ion-osmoregulatory plasticity in European sea bass (Dicentrarchus labrax) juveniles under complex scenarios of salinity variation, ocean acidification and high ammonia challenge. Aquat. Toxicol. 212, 54-69. doi:10.1016/j.aquatox.2019.04.024.

Sokolova, I. (2018). Mitochondrial Adaptations to Variable Environments and Their Role in Animals' Stress Tolerance. Integr. Comp. Biol. 58, 519-531. doi:10.1093/icb/icy017.

Sordo, L., Santos, R., Reis, J., Shulika, A., and Silva, J. (2016). A direct CO2 control system for ocean 
bioRxiv preprint doi: https://doi org/10.1101/2021.04 16 440165; this version posted April 18, 2021. The copyright holder for this preprint (which was not certified by peer review) is the author/funder, who has granted bioRxiv a license to display the preprint in perpetuity. It is made available under aCC-BY-NC-ND 4.0 International license.

acidification experiments: testing effects on the coralline red algae Phymatolithon lusitanicum. PeerJ 4, e2503. doi:10.7717/peerj.2503.

Therneau, T. M. (2021). Survival Analysis [R package survival version 3.2-10]. Available at: https://CRAN.R-project.org/package=survival.

Therneau, T. M., and Grambsch, P. M. (2000). Modeling Survival Data: Extending the Cox Model. Statistics for Biology and Health. doi:10.1007/978-1-4757-3294-8.

Toa, D. G., Afonso, L. O. B., and Iwama, G. K. (2004). Stress response of juvenile rainbow trout (Oncorhynchus mykiss)to chemical cues released from stressed conspecifics. Fish Physiol. Biochem. 30, 103-108. doi:10.1007/s10695-005-0266-5.

Tomsic, D., Sztarker, J., Berón de Astrada, M., Oliva, D., and Lanza, E. (2017). The predator and prey behaviors of crabs: from ecology to neural adaptations. J. Exp. Biol. 220, 2318-2327. doi:10.1242/jeb.143222.

Torchiano, M. (2020). Efficient Effect Size Computation [R package effsize version 0.8.1]. Available at: https://CRAN.R-project.org/package=effsize.

Truchot, J. P., and Duhamel-Jouve, A. (1980). Oxygen and carbon dioxide in the marine intertidal environment: diurnal and tidal changes in rockpools. Respir. Physiol. 39, 241-254. doi:10.1016/00345687(80)90056-0.

Wage, J., Rohr, S., Hardege, J. D., and Rotchell, J. M. (2016). Short-term effects of CO2-induced low pH exposure on target gene expression in Platynereis dumerilii. Journal of Marine Biology \& Oceanography 5, 2. doi:10.4172/2324-8661.1000155.

Wang, Y., Hu, M., Wu, F., Storch, D., and Pörtner, H.-O. (2018). Elevated pCO2 affects feeding behavior and acute physiological response of the brown crab Cancer pagurus. Front. Physiol. 9, 1164. doi:10.3389/fphys.2018.01164.

Watson, G. J., Hamilton, K. M., and Tuffnail, W. E. (2005). Chemical alarm signalling in the polychaete Nereis (Neanthes) virens (Sars) (Annelida: Polychaeta). Anim. Behav. 70, 1125-1132. doi:10.1016/j.anbehav.2005.03.011.

Wolfe, K., Nguyen, H. D., Davey, M., and Byrne, M. (2020). Characterizing biogeochemical fluctuations in a world of extremes: A synthesis for temperate intertidal habitats in the face of global change. Glob. Chang. Biol. 26, 3858-3879. doi:10.1111/gcb.15103.

Wyatt, T. D., Hardege, J. D., and Terschak, J. (2014). Ocean acidification foils chemical signals. Science 346, 176. doi:10.1126/science.346.6206.176-a. 
bioRxiv preprint doi: https://doi org/10.1101/2021.04.16.440165; this version posted April 18, 2021. The copyright holder for this preprint (which was not certified by peer review) is the author/funder, who has granted bioRxiv a license to display the preprint in perpetuity. It is made available under aCC-BY-NC-ND 4.0 International license.

595

596

597

598

599

600

601

602

603

604

605

606

607

608

\section{Tables}

Table 1. Results of Cox proportional hazard model for the main effects of predictors (pH drop, stress metabolites, donor) on the time-to-success analysis in small hermit crab (Diogenes pugilator, $\mathrm{n}=320$ observations with 120 events of finding a food cue), green shore crab (Carcinus maenas, $\mathrm{n}=189$ observations with 122 events of finding a food cue), and harbour ragworm (Hediste diversicolor, $\mathrm{n}=325$ observations with 234 events of burrowing head in sediment). Unsuccessful observations are censored. Significance $(\mathrm{P} \leq 0.05)$ is shown by p-values in bold. Overall significance of the models using Likelihood ratio tests were: $D$. pugilator: $\mathrm{P}=0.06 ;$ C. maenas: $\mathrm{P}=0.009 ;$ H. diversicolor: $\mathrm{P}<0.0001)$. Covariates were dropped from models after analyses of deviance showed that they passed the Chi-squared test $(D$. pugilator: number of water uses: $\mathrm{P}=$ 0.1163, crab size: $\mathrm{P}=0.6318$; . maenas: number of water uses: $\mathrm{P}=0.6104$, crab size: $\mathrm{P}=0.9995$, year: $\mathrm{P}=$ 0.3348; H. diversicolor: number of water uses: $\mathrm{P}=0.2649$ ). Success ratio (aka hazard ratio) is the exponentiated estimate. SE is the standard error of estimate.

\begin{tabular}{rllllll}
\hline Predictors & Success (hazard) ratio & Estimate & SE & Z & P \\
\hline D. pugilator & & & & & \\
& pH drop & $\mathbf{0 . 4 7 0 2}$ & -0.7546 & 0.3530 & -2.1378 & $\mathbf{0 . 0 3 2 5}$ \\
& donor & $\mathbf{0 . 3 4 6 0}$ & -0.2100 & 0.3167 & -0.6631 & 0.5073 \\
stress metabolites & -1.0613 & 0.3843 & -2.7613 & $\mathbf{0 . 0 0 5 8}$ \\
& pH drop:stress metabolites & 1.7878 & 0.5810 & 0.4858 & 1.1959 & 0.2317 \\
pH drop:donor & $\mathbf{3 . 2 8 4 2}$ & 1.1891 & 0.5441 & 2.1853 & $\mathbf{0 . 0 2 8 9}$ \\
stress metabolites:donor & 1.4970 & 0.4034 & 0.5326 & 0.7575 & 0.4487 \\
pH drop:stress metabolites:donor & 0.4168 & -0.8752 & 0.7498 & -1.1672 & 0.2431 \\
& & & & & \\
maenas & & & & & \\
& pH drop & 0.7490 & -0.2890 & 0.3620 & -0.7982 & 0.4247 \\
& 1.2156 & 0.1953 & 0.2887 & 0.6762 & 0.4989 \\
& donor & 1.4445 & 0.3678 & 0.3385 & 1.0865 & 0.2773 \\
& stress metabolites & -0.1422 & 0.4630 & -0.3072 & 0.7587 \\
H. diversicolor & -1.2484 & 0.6312 & -1.9777 & $\mathbf{0 . 0 4 8 0}$ \\
& pH drop:stress metabolite & 0.8674 & -1.2102 & 0.5008 & -2.4165 & $\mathbf{0 . 0 1 5 7}$ \\
pH drop:donor & $\mathbf{0 . 2 8 7 0}$ & 1.7963 & 0.8261 & 2.1743 & $\mathbf{0 . 0 2 9 7}$ \\
& stress metabolites:donor & $\mathbf{0 . 2 9 8 1}$ & & & & \\
& $\mathbf{6 . 0 2 7 3}$ & & & & \\
& & & -1.1899 & 0.3045 & -3.9075 & $<\mathbf{0 . 0 0 0 1}$ \\
& pH drop & $\mathbf{0 . 3 0 4 3}$ & -1.0442 & 0.3049 & -3.4251 & $\mathbf{0 . 0 0 0 6}$ \\
stress metabolites:donor & -0.3616 & 0.2258 & -1.6013 & 0.1093 \\
stress metabolites & $\mathbf{0 . 3 5 2 0}$ & 1.3841 & 0.4411 & 3.1376 & $\mathbf{0 . 0 0 1 7}$ \\
donor & 0.6965 & 0.9030 & 0.3816 & 2.3663 & $\mathbf{0 . 0 1 8 0}$ \\
pH drop:stress metabolites & $\mathbf{3 . 9 9 1 4}$ & 0.5492 & 0.3816 & 1.4390 & 0.1501 \\
pH drop:donor & $\mathbf{2 . 4 6 6 9}$ & -1.4736 & 0.5633 & -2.6158 & $\mathbf{0 . 0 0 8 9}$ \\
\hline pH drop:stress metabolites:donor & 1.7318 & & & &
\end{tabular}

609 
bioRxiv preprint doi: https://doi org/10.1101/2021.04.16.440165; this version posted April 18, 2021. The copyright holder for this preprint (which was not certified by peer review) is the author/funder, who has granted bioRxiv a license to display the preprint in perpetuity. It is made available under aCC-BY-NC-ND 4.0 International license.

610 Table 2. Results of the binomial generalised linear model for the main effects of predictors ( $\mathrm{pH}$ drop, stress 611 metabolites, donor) on the avoidance behaviour in small hermit crab (Diogenes pugilator, $\mathrm{n}=320$ observations 612 of finding a food cue), green shore crab (Carcinus maenas, $\mathrm{n}=151$ observations of finding a food cue), and 613 harbour ragworm (Hediste diversicolor, $\mathrm{n}=325$ observations of burrowing head in sediment). Due to missing 614 observations in conspecific control metabolites at control $\mathrm{pH}$ in Hediste diversicolor, data was analysed with 615 two models. Model 1: effect of donor across all treatments (sample size: 253 observations). Model 2: effects 616 of $\mathrm{pH}$ and metabolites in subset receiving $S$. aurata metabolites (sample size: 154 observations). Overall 617 significance of models from Chi-squared analyses of deviance when including only predictors were: $D$. 618 pugilator: $\mathrm{P}<0.0001 ;$ C. maenas: $\mathrm{P}<0.0001 ;$ H. diversicolor: $\mathrm{P}<0.0001$ (model 1) and $\mathrm{P}<0.0001$ (model 619 2). Covariates were dropped from models after analyses of deviance showed that they passed the Chi-squared 620 test (D. pugilator: number of water uses: $\mathrm{P}=0.5963$, crab size: $\mathrm{P}=0.9158 ;$ C. maenas: crab size: $\mathrm{P}=0.2710$ ). 621 Significance $(\mathrm{P} \leq 0.05)$ is shown by $\mathrm{p}$-values in bold. $\mathrm{SE}$ is the standard error of estimate.

622

Predictors Estimate SE Z $\mathbf{P}$ D. pugilator

$\begin{array}{rllll}\text { (Intercept) } & -0.9694 & 0.3541 & -2.7380 & 0.0062 \\ \text { pH drop } & 0.1221 & 0.4944 & 0.2470 & 0.8049 \\ \text { stress metabolites } & -0.1292 & 0.5086 & -0.2540 & 0.7995 \\ \text { donor } & 1.1701 & 0.4758 & \mathbf{2 . 4 5 9 0} & \mathbf{0 . 0 1 3 9} \\ \text { pH drop:stress metabolites } & -0.2603 & 0.7219 & -0.3610 & 0.7185 \\ \text { pH drop:donor } & 0.7758 & 0.6919 & 1.1210 & 0.2622 \\ \text { stress metabolites:donor } & 1.0272 & 0.7022 & 1.4630 & 0.1435 \\ \text { pH drop:stress metabolites:donor } & -0.8890 & 1.0039 & -0.8860 & 0.3759\end{array}$

\section{C. maenas}

\begin{tabular}{|c|c|c|c|c|}
\hline (Intercept) & -0.2224 & 0.6725 & -0.3307 & 0.7409 \\
\hline $\mathrm{pH}$ drop & -1.1263 & 0.9173 & -1.2279 & 0.2195 \\
\hline stress metabolites & -1.1263 & 0.9173 & -1.2279 & 0.2195 \\
\hline donor & -0.4626 & 0.8326 & -0.5556 & 0.5785 \\
\hline number of water uses & -0.3077 & 0.1556 & -1.9772 & 0.0480 \\
\hline pH drop:stress metabolites & 2.2527 & 1.2978 & 1.7357 & 0.0826 \\
\hline $\mathrm{pH}$ drop:donor & 5.5551 & 1.5392 & 3.6090 & 0.0003 \\
\hline stress metabolites:donor & 3.8799 & 1.2465 & 3.1127 & 0.0019 \\
\hline op:stress metabolites:donor & -7.5415 & 1.9329 & -3.9017 & 0.0001 \\
\hline
\end{tabular}

\section{H. diversicolor}

Model 1 (both donors)

(Intercept) donor

number of water uses

Model 2 (S. aurata donor)

$$
\begin{array}{r}
\text { (Intercept) } \\
\text { pH drop }
\end{array}
$$

stress metabolites $\mathrm{pH}$ drop:stress metabolites

0.2801
1.0944
-0.7745

-0.6931
-18.8729
3.3557
16.2548

0.3790

0.3169

0.1462

0.5000

1603.1137

0.7788

0.7391

3.4534

$-5.2980$

$-1.3863$

$-0.0118$

0.9906 1603.1138

0.4598

0.0006 $<0.0001$

623 


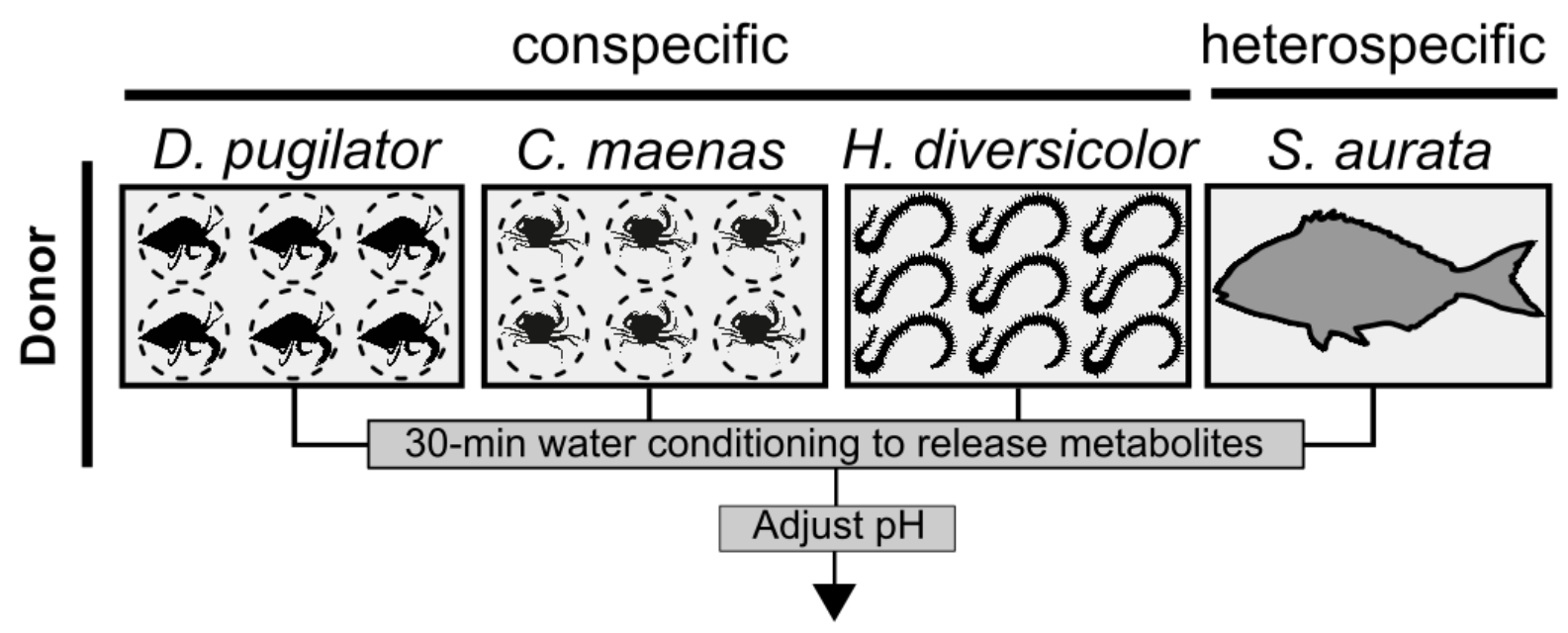

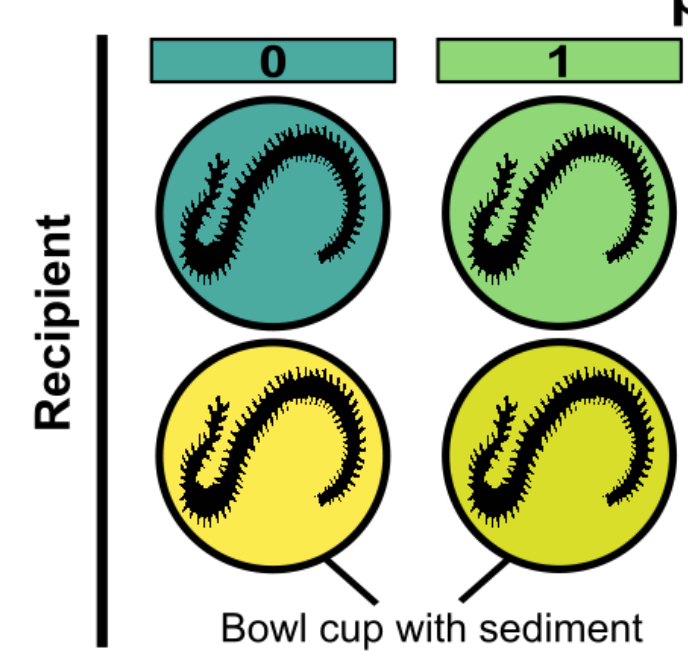

5-min burrowing success assay
pH drop

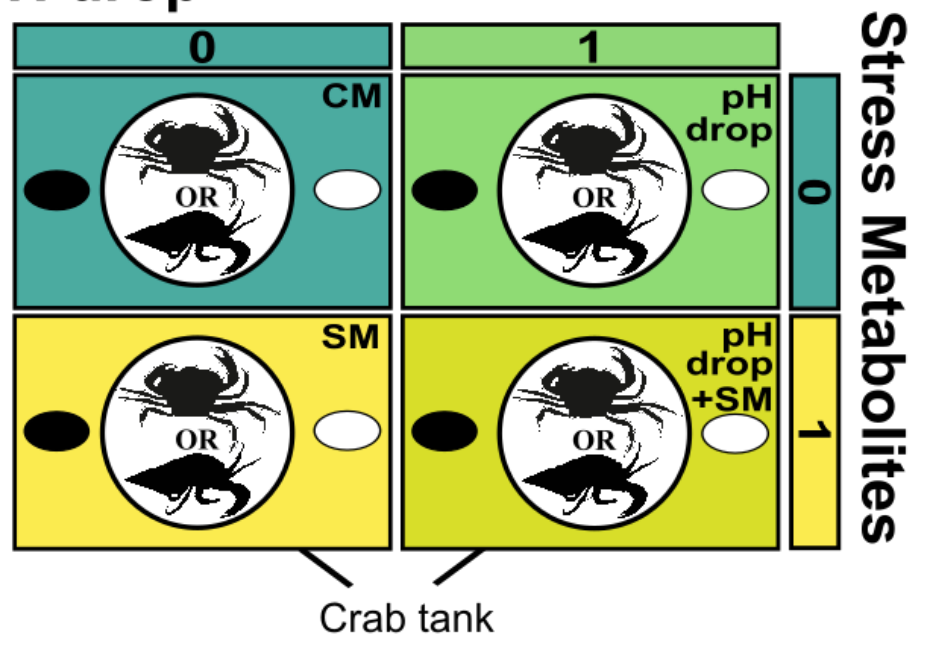

5-min feeding success assay

+ respiration $(1)$
625

Figure 1. Schematic experimental design showing the presence vs. absence of predictors ( $\mathrm{pH}$ drop, stress metabolites, donor). Behavioural effects of short-term acute $\mathrm{pH}$ drop and stress metabolites it induced were tested in three species: Diogenes pugilator, Carcinus maenas, and Hediste diversicolor. Metabolites were obtained by conditioning donors in either control $\mathrm{pH}=8.2$ (releasing putative control metabolites), or $\mathrm{pH}$ drop $=7.6$ (releasing putative stress metabolites), followed by $\mathrm{pH}$ adjustments for factorial design yielding four experimental conditions $\mathrm{CM}, \mathrm{pH}$ drop, $\mathrm{SM}$, and $\mathrm{pH}$ drop+SM. Predictors are binary coded as 0 (control metabolites, control $\mathrm{pH}$ ) and 1 (stress metabolites, $\mathrm{pH}$ drop). Metabolites originated from conspecifics or the heterospecific Sparus aurata. Behaviour assays for crabs consisted in locating a feeding cue in 300 seconds. Specimens of $H$. diversicolor were placed on top of sediment and burrowing behaviour was recorded for 300 seconds. A range of avoidance behaviours were also recorded. After completing the feeding assay, C. maenas additionally underwent five minutes of respiration rate measurements. Experimental conditions were CM: control metabolites in control $\mathrm{pH}, \mathrm{SM}$ : control metabolites in control $\mathrm{pH}, \mathrm{pH}$ drop: control metabolites in $\mathrm{pH}$ drop, $\mathrm{pH}$ drop+SM: stress metabolites in $\mathrm{pH}$ drop. Animal drawings by A. Murcia and KCWV. 


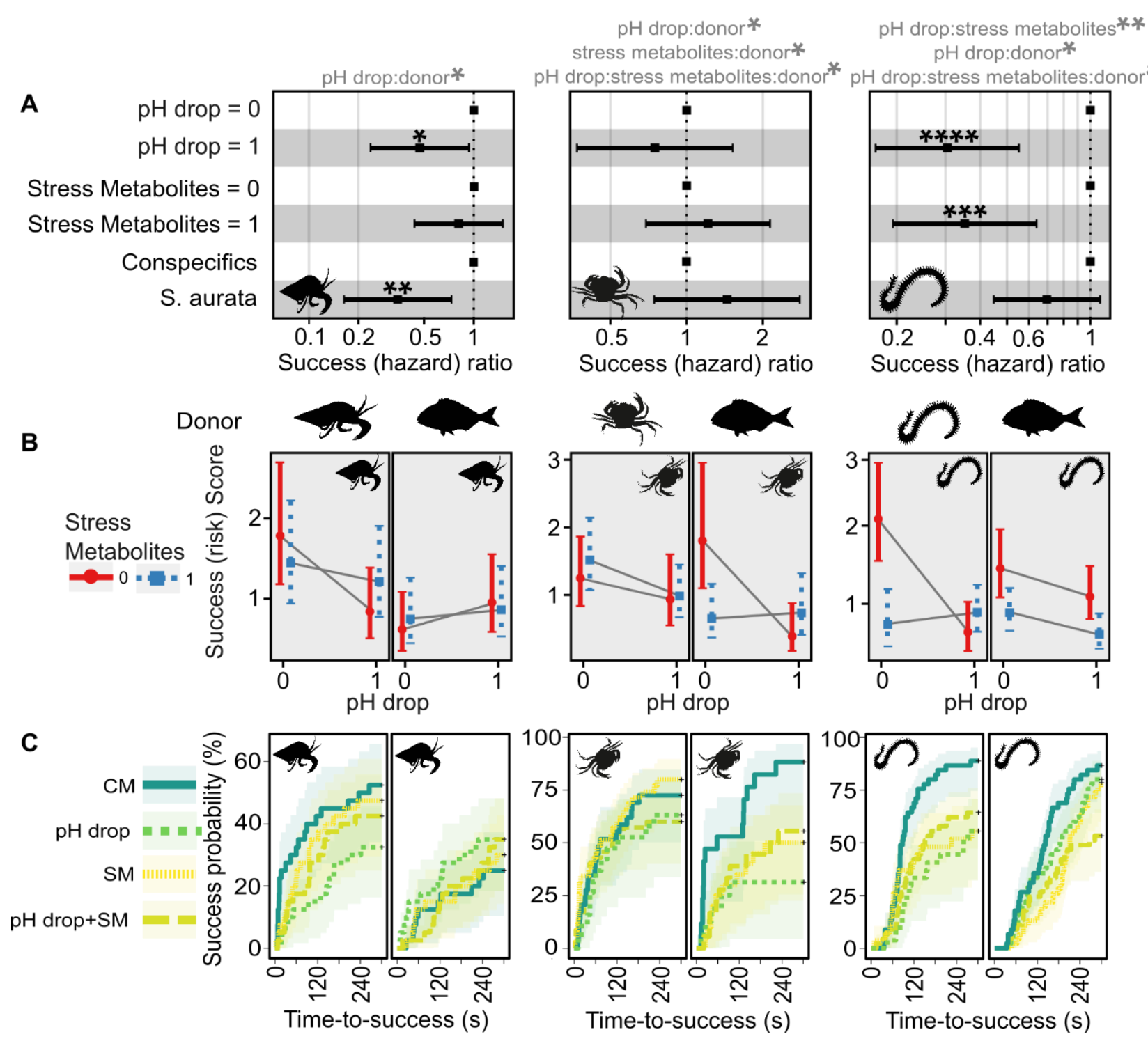

Figure 2. Effects of predictors ( $\mathrm{pH}$ drop, stress metabolites, donor) on time-to-success in Diogenes pugilator,

641 Carcinus maenas, and Hediste diversicolor. A) effects of predictors on success ratio (aka hazard ratio with 642 success as event, arbitrary units). Likelihood ratio tests for overall model fit were: D. pugilator: $\mathrm{P}=0.06 ; C$. 643 maenas: $\mathrm{P}=0.009 ;$ H. diversicolor: $\mathrm{P}<0.0001)$. Significant predictors from Cox proportional hazard models 644 are shown with asterisks, and significant interaction terms are shown in grey above the plots. B) Interaction 645 term plot of marginal effects showing predicted success score (aka risk score with success as event, arbitrary 646 units \pm confidence interval) split by donor and recipient species. Crossed solid grey lines represent an 647 interacting effect of $\mathrm{pH}$ and metabolites. C) Kaplan-Meier curves to visualise success probability (cumulative 648 event) for each experimental condition over time. *: $\mathrm{P} \leq 0.05$, **: $\mathrm{P}<0.01, * * *: \mathrm{P}<0.001, * * * *: \mathrm{P}<0.0001$. 649 Experimental treatments were: $\mathrm{CM}$ : control metabolites in control $\mathrm{pH}, \mathrm{pH}$ drop: control metabolites in $\mathrm{pH}$ 650 drop, SM: stress metabolites in control pH, $\mathrm{pH}$ drop+SM: stress metabolites in $\mathrm{pH}$ drop. 

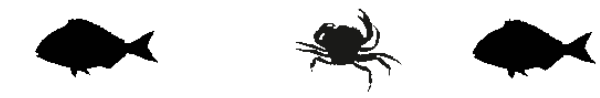

water use* $\mathrm{pH}$ drop:donor *** stress metabolites:donork*

A

donor*

pH drop:stress metabolites:donor ${ }^{\text {**k* }}$

stress metabolites*****
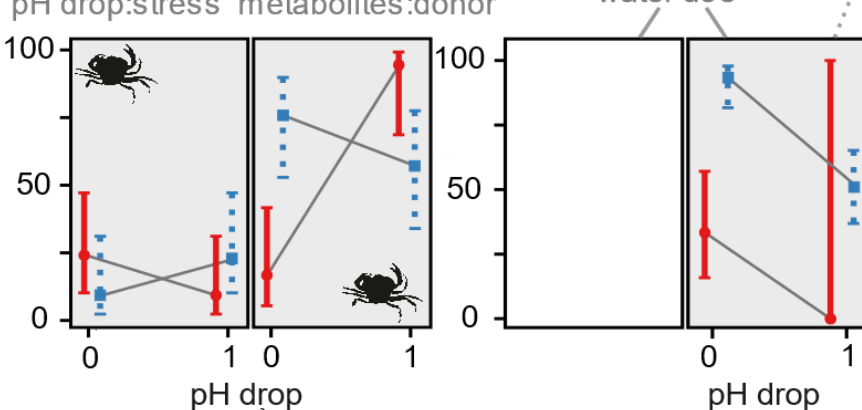

$\stackrel{4}{5}$

B
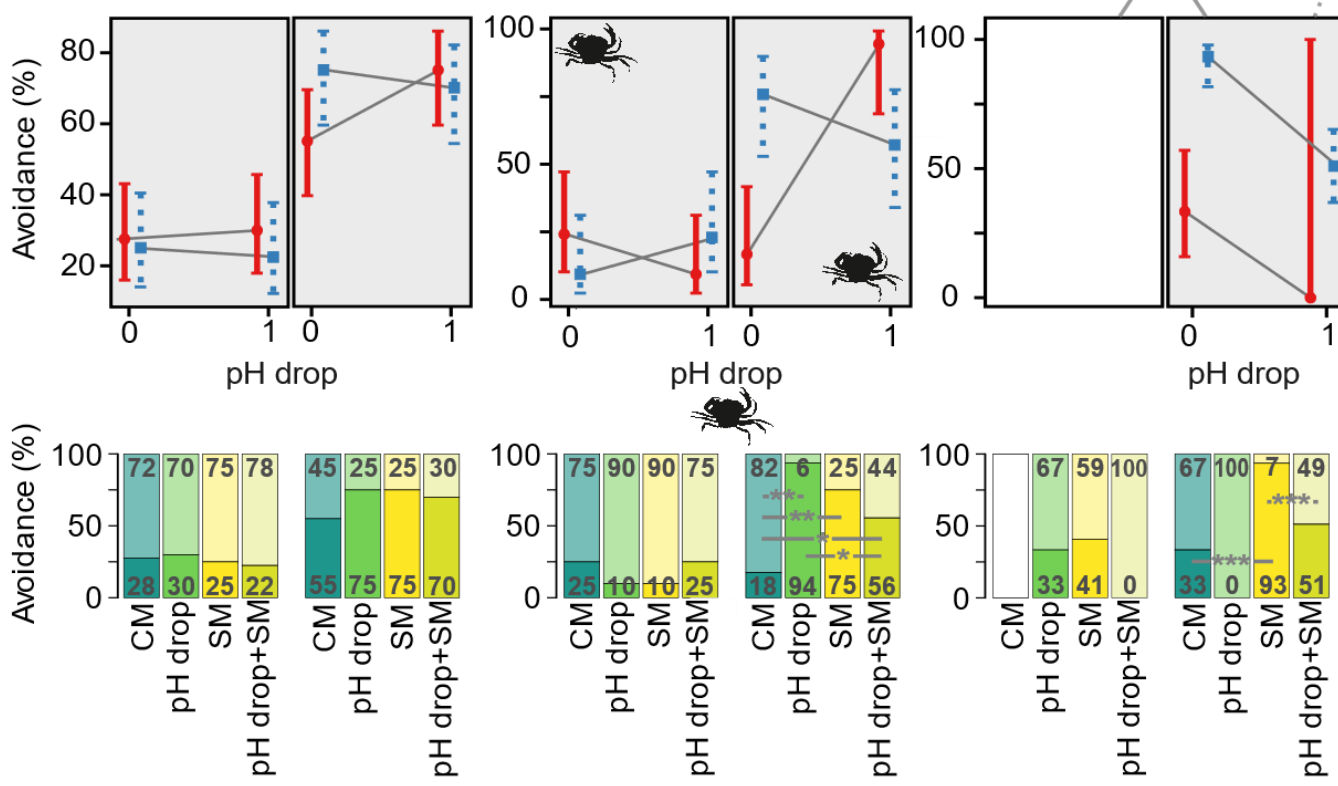

Figure 3. Effects of predictors (pH drop, stress metabolites, donor) on the percentage of avoidance behaviour in Diogenes pugilator, Carcinus maenas, and Hediste diversicolor. Avoidance behaviour included freezing and escaping (D. pugilator and C. maenas), or freezing, curling, flipping, and slime secretion (H. diversicolor). A) Split bars represent the presence (dark area) or absence (light area) of avoidance behaviours. Significant main predictors (and their interaction terms) and covariates are shown above plots. Significant pairwise comparisons between treatments in each donor/recipient are shown as horizontal grey lines. *: $\mathrm{P} \leq 0.05,{ }^{*}$ : $\mathrm{P}$ $<0.01, * * *: \mathrm{P}<0.001, * * * *: \mathrm{P}<0.0001$. Experimental treatments were: CM: control metabolites in control $\mathrm{pH}, \mathrm{pH}$ drop: control metabolites in $\mathrm{pH}$ drop, $\mathrm{SM}$ : stress metabolites in control $\mathrm{pH}, \mathrm{pH}$ drop+SM: stress metabolites in $\mathrm{pH}$ drop. (B) Interaction plot showing the marginal effects on the predicted avoidance percentages ( \pm confidence interval) of stress metabolites and $\mathrm{pH}$ drop within the conspecific and heterospecific groups for each species. Crossing solid grey lines represent an interacting effect of $\mathrm{pH}$ and metabolites for each donor. The interactive effects of predictors for H. diversicolor/H. diversicolor are not represented due to the missing CM treatment. Overall effects of donor and water use across the response of $H$. diversicolor (for either donor) are shown with solid lines, whereas the effects of stress metabolites are for $\mathrm{S}$. aurata/H. diversicolor only (grey dashed line). 